\title{
An Evaluation of The İmpact of War on Pregnancy in Syrian Refugee Women: A Retrospective Study
}

\author{
Ammar KANAWATI ${ }^{1}$, Hediye DAĞDEVIREN ${ }^{2 *}$
}

\begin{abstract}
Objective: The aim of this study was to investigate the perinatal and postpartum results of refugee Syrian pregnant women in Turkey and to evaluate the effect of the war on pregnancy.
\end{abstract}

Material and Methods: In the study, a total of 1020 women applying for pregnancy and giving birth at Bakırkoy Dr. Sadi Konuk Training and Research Hospital, Department of Gynecology and Obstetrics Clinic between the 2014 January-2016 January dates were included, 509 of whom were Syrian refugees and 511 of whom were Turkish. By examining the files belonging to the patients retrospectively, the number of gravida, parity, birth and abortus were determined; normal, vaginal birth and caesarean section as a delivery method were recorded separately. Parameters for the birth and infants were determined individually.

Results: When the demographic information of the patients included in the study were evaluated, it was found that the age of Syrian women was significantly lower than those of Turkish women. $(\mathrm{p}<0.05)$. In addition, the gestational week in Syrian women was significantly lower than those of Turkish women $(p<0.05)$. When the birth weight of both groups was compared, the birth weight of the Syrian women was significantly lower than those of Turkish women $(p<0.05)$. Another parameter assessed during our study is the delivery method: The cesarean delivery rate of the Syrian women was determined significantly lower than those of Turkish women $(p<0.05)$. No significant difference was observed between the two groups in the other parameters evaluated $(p>0,05)$.

Conclusion: In order to improve the antenatal care of the Syrian immigrant women; we are on the opinion that it is necessary to create ideal solutions by working with international organizations about communication and language.

Keywords: Pregnancy, Syrian immigrants, prenatal parameter

${ }^{1}$ Bakirkoy Dr. Sadi Konuk Teaching and Research Hospital, Department of Gynecology and Obstetrics, Istanbul, Turkey

${ }^{2}$ Istanbul Aydin University, Faculty of Medicine, Department of Gynecology and Obstetrics,

Istanbul, Turkey

*Corresponding author

E-mail: hediyedagdeviren@gmail.com; ORCID: 0000-0002-9384-4514

Ammar Kanawati:dr.ammarkanawati@gmail.com; ORCID: 0000-0001-6180-4385

Received: 24 May 2021 Revised: 2 October 2021 Accepted: 10 October 2021

DOI: 10.17932/EJOH.2020.022/ejoh v02i2003 


\section{Introduction}

Since 2011, the number of Syrian refugees in Turkey due has been increased to 3.500 .000 as of 2019 and $50 \%$ of them are women. Of Syrian refugees, $10 \%$ live in the camps in 10 provinces and 90\% live in different cities of Turkey (1). In Turkey's conditions, pregnant women, living outside the camp, has difficulty in access to health services, gives birth under insufficient conditions and has difficulty in access to birth control aids and the lack of information on birth control methods $(2,3)$. Pregnancy is a physiological process, in some cases, it can lead to many events that may pose a life threat to both the mother and the fetus. One of the conditions that may create both morbidity or mortality risks to both the fetus and the mother is, of course, war. In the studies investigating the immigrant women who do not have adequate care during pregnancy, pregnancy diabetes, postpartum hemorrhage, perineal trauma and cesarean birth rates are reported to be quite high (4). Any medical problems that may occur in prenatal and postnatal periods during pregnancy may lead to serious complications and psychiatric disorders. On the other hand, this may affect the person's view of pregnancy and the desire to conceive again.

In the literature, evaluations about antenatal care, pregnancy and postpartum period have been made in Syrian immigrants. The main blood serum parameters of Syrian immigrants, the number of antenatal visits, vitamin and iron supplementation recommended during pregnancy were assessed. In addition, postpartum height and weight of the infant and neonatal intensive care need are also included in the evaluation. However, in the literature no studies evaluating the impact of war on pregnancy within the context of these pregnancies and comparing the perinatal parameters of the pregnant Syrians with the pregnant Turkish were found.

Access to health care should be an independent case of a person's immigrant status, it is not included as a right in the 1951 Geneva Convention, the chief legal document stating the rights of refugees and the responsibilities of host countries. Universal Declaration of Human Rights (1948), International Covenant on Economic, Social and Cultural Rights (1966), International Covenant on Civil and Political Rights (1966), International Convention on the Elimination of All Forms of Racial Discrimination (1965), Elimination of All Forms of Discrimination against Women, The combination of various legal instruments, such as the Convention (1979), the United Nations Convention against Torture and Other Cruel, Inhuman or Degrading Treatment or Punishment (1984), the Convention on the Rights of the Child (1990), makes health a fundamental human right that transcends issues of citizenship and political status. 
Refugees fleeing human-made disasters become vulnerable to certain health risks due to the trauma caused by the experience of displacement, violence in conflict situations, and the harsh living conditions (lack of food, water, and hygiene) they are exposed to during and after migration. In addition to severe mental illness, the health problems associated with the mass influx of refugees include infectious, communicable, non-infectious, or chronic diseases are also included. According to the academic literature and international reports, some of the most common health problems in immigrants are listed below: Malnutrition, diarrhea, measles, malaria, respiratory infections, growth and developmental disorders in children, anemia, physical violence and related injuries, sexual abuse, sexually transmitted diseases, including HIV/AIDS, pregnancy and childbirth complications, chronic diseases and complications. Mental diseases such as depression, anxiety disorder, sleep disorder and post-traumatic stress disorder. There is a direct cause-effect relationship between malnutrition, malaria, measles, diarrheal diseases and respiratory infections, and death rates especially in the emergency phase, that is, in the first days and weeks following the migration influx. The effects of other common diseases are not associated with mortality rates, but these diseases also pose serious challenges for the displaced masses. If an effective refugee health service is not provided; Diseases such as hepatitis A, hepatitis B, sexually transmitted diseases (HIV/AIDS), measles and tuberculosis can pose serious threats to the health of refugees and local people. Refugees often face barriers to accessing local health and social services, depending on some legal, cultural, social, and economic factors in the countries they live in.

There is a growing literature on the experience of refugee population access to health services in different countries. The scarcity of properly trained interpreters, the complexity or ignorance of referral procedures, the lack of information about the services provided, and the mixing of the roles of different health professionals are other barriers to accessing health services. There are many studies focusing about Syrian refugee women in Turkey. Although Human Rights Watch (2014), AFAD (2014), and Mazlumder (2014) do not specifically address health issues, they do reveal the conditions faced by Syrian refugee women in Turkey. Grove (2015) (5) focused on the serious health risks faced by Syrian refugee women, based on information from the cited Human Rights Watch (2014) and AFAD (2014) reports. Şimşek et al. (2017) (6) conducted a comprehensive research on the health indicators of Syrian refugee women living in the Şanliurfa region. Kahyaoğlu Süt (2017), Başel et al. (2006) (7) and Bahadır \& Uçku (2015) (8) evaluated the reproductive health indicators of Syrian refugee women. In addition, Büyüktiryaki et al. (2015) (9) analyze the newborn outcomes of Syrian refugees who gave birth in a hospital in Ankara. 
Erenel et al. (2017) (10) compare the pregnancy outcomes of Syrians with those of Turkish citizens and conclude that Syrian refugees lack adequate prenatal care. Tolunay et al. (2016) (11) specifically focus on pregnancy-related intraocular pressure changes in Syrian refugee women.

sIn this cross-sectional study, it was aimed to evaluate the effects of war on pregnancy. For this purpose, perinatal and postpartum results of Syrian women who came to Turkey due to the war between the 2014-2015 years and gave birth at Bakırköy Dr Sadi Konuk Training and Research Hospital were investigated, and the effect of the war on pregnancy by comparing the results obtained from Syrian women with the results from Turkish patients selected randomly who gave birth in the same date range were assessed. According to our knowledge, this research is the first study evaluating the impact of war on pregnancy in Syrian women.

\section{Methods}

In the study, a total of 1020 women applying for pregnancy and giving birth at Bakırköy Dr Sadi Konuk Training and Research Hospital, Department of Gynecology and Obstetrics Clinic between the March 2014- March 2015 dates were included, 509 of whom were Syrian refugees and 511 of whom were from Turkey. By examining the files belonging to the patients retrospectively, the number of gravida, parity, birth and abortus were determined; normal, vaginal birth and caesarean section as a delivery method were recorded separately. Parameters for the birth and infants were determined individually. All subjects gave their informed consent for inclusion before they participated in the study. The study was conducted in accordance with the Declaration of Helsinki, and the protocol was approved by the Ethics Committee of Bakırköy Dr Sadi Konuk Training and Research Hospital.

Mean, standard deviation, median, minimum-maximum, frequency and ratio values were used in descriptive statistics of the data. The distribution of variables was checked with Kolmogorov-Smirnov test. Mann-Whitney U test was used for the analysis of quantitative data. Chi-square test was used for the analysis of qualitative data. SPSS 22.0 software package was used for analysis. 


\section{Results}

When the demographic information of the patients included in the study were evaluated, the age of Syrian women was significantly determined lower than those of Turkish women $(\mathrm{p}<0.05)$. However, no significant difference was detected between the two groups in terms of gravida, parity, and abortion rates (Figure 1).

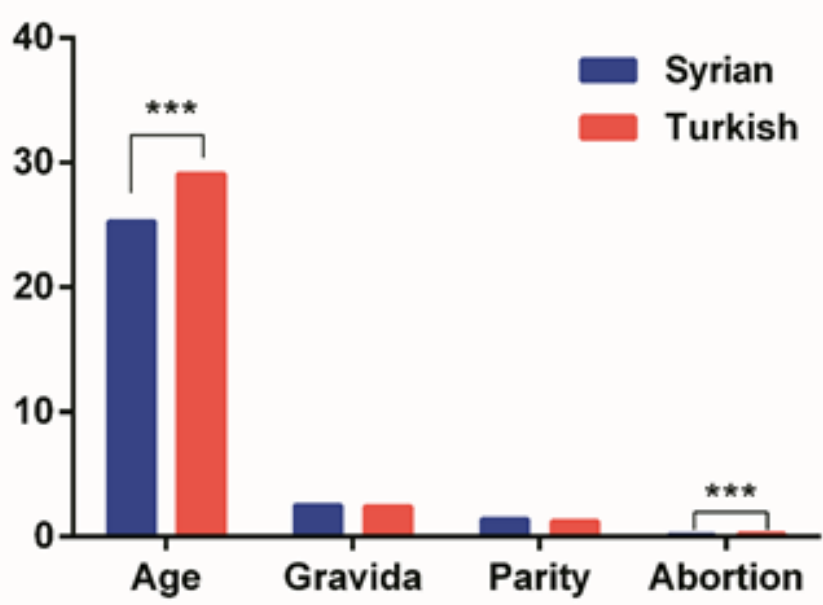

Figure 1. Comparison of perinatal parameters between the groups $(* * * p<0,05)$

Another parameter assessed during our study is the type of delivery: The cesarean delivery rate of the Syrian women was significantly determined lower than those of Turkish women $(p<0.05$; Figure 2$)$. When the delivery method of the patients was observed, it was determined that in Syrian patients the normal birth rate was $65,6 \%$, cesarean rate was $33.6 \%$ and external birth (outside hospital) was $0.8 \%$ while it was determined that the normal birth rate was $51.1 \%$, the cesarean rate was $47.9 \%$ and the external birth rate was $1.0 \%$ in Turkish patients. 


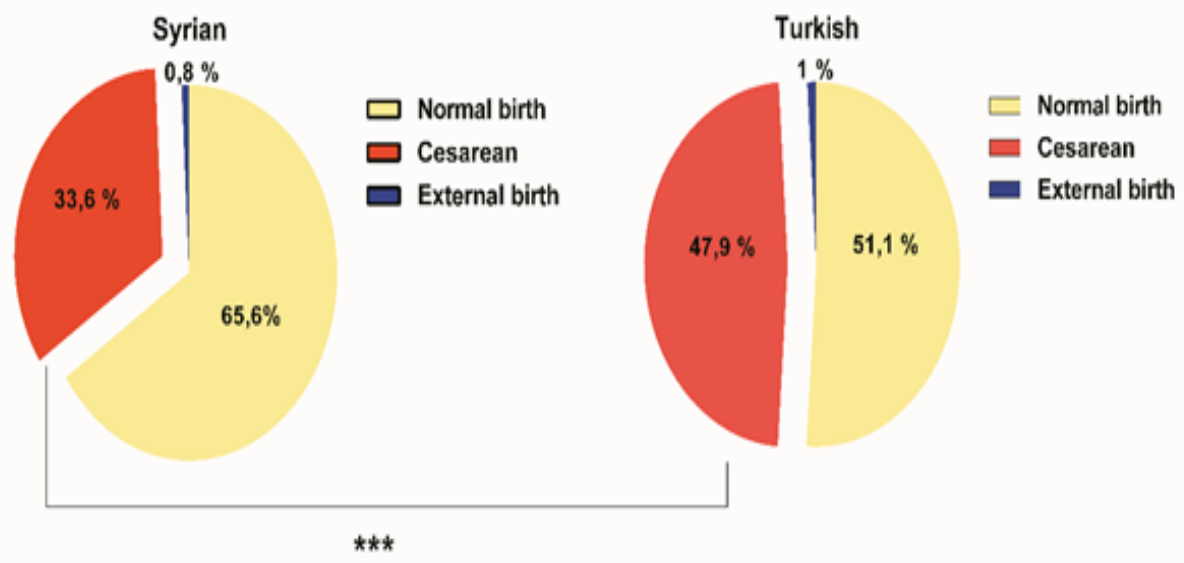

Figure 2. Birth rates $(* * * p<0,05)$

The gestational week in Syrian women was significantly detected lower than those of Turkish women ( $<0.05$; Figure 3$)$. Besides, when the birth weight of both groups was compared, the birth weight of the Syrian women was determined significantly lower than those of Turkish women $(\mathrm{p}<0.05$; Figure 3$)$.

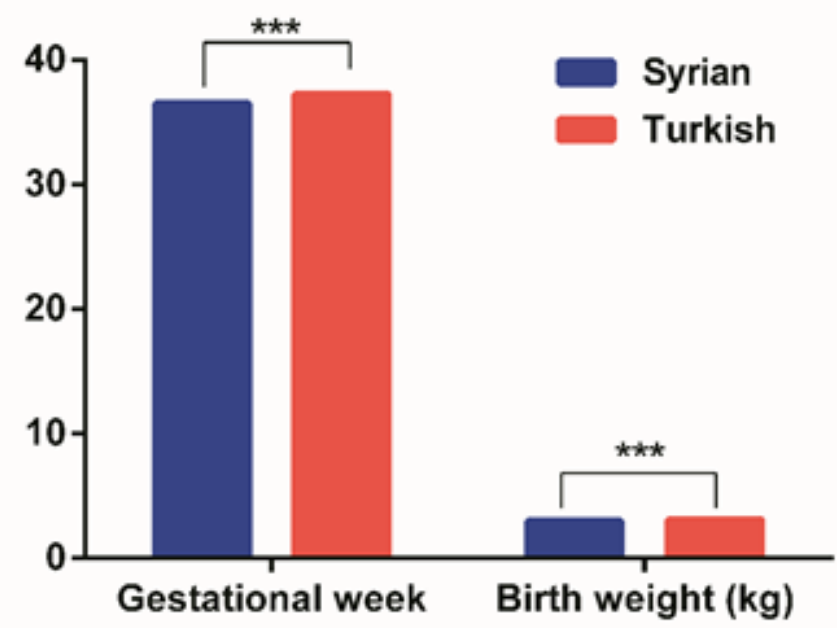

Figure 3. Comparison of gestational week and birth weight of the groups

$$
(* * * p<0,05)
$$


Finally, Syrian women's Apgar values (Figure 4) and perinatal mortality rates (Figure 5) in the first minute and fifth minute were compared. No significant differences were found in the comparison $(p>0.05)$ (Table 1).

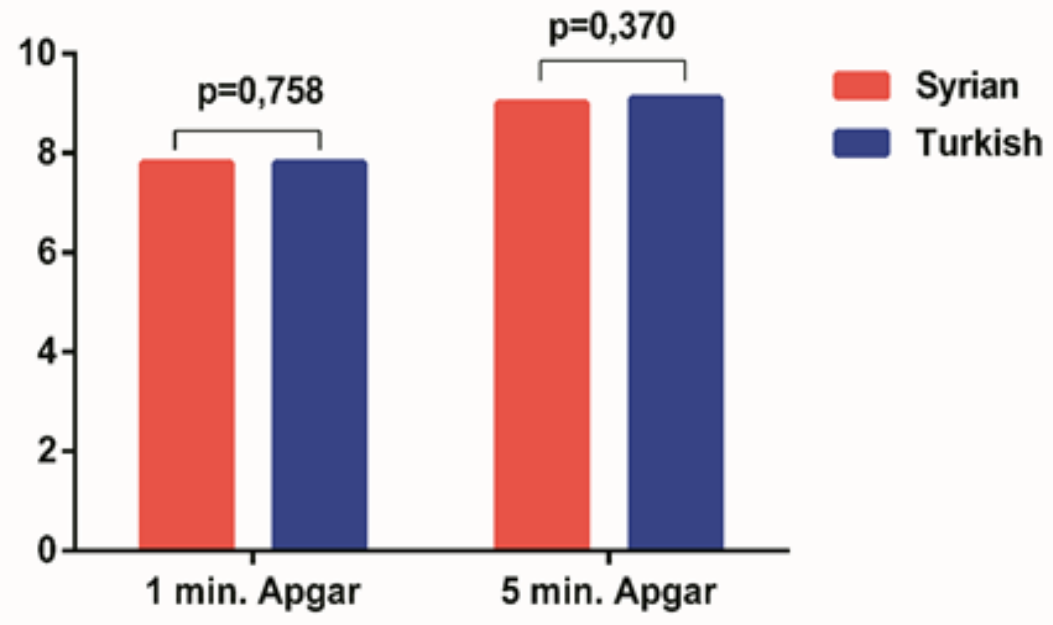

Figure 4. Recorded Apgar score of 1 and 5 minutes

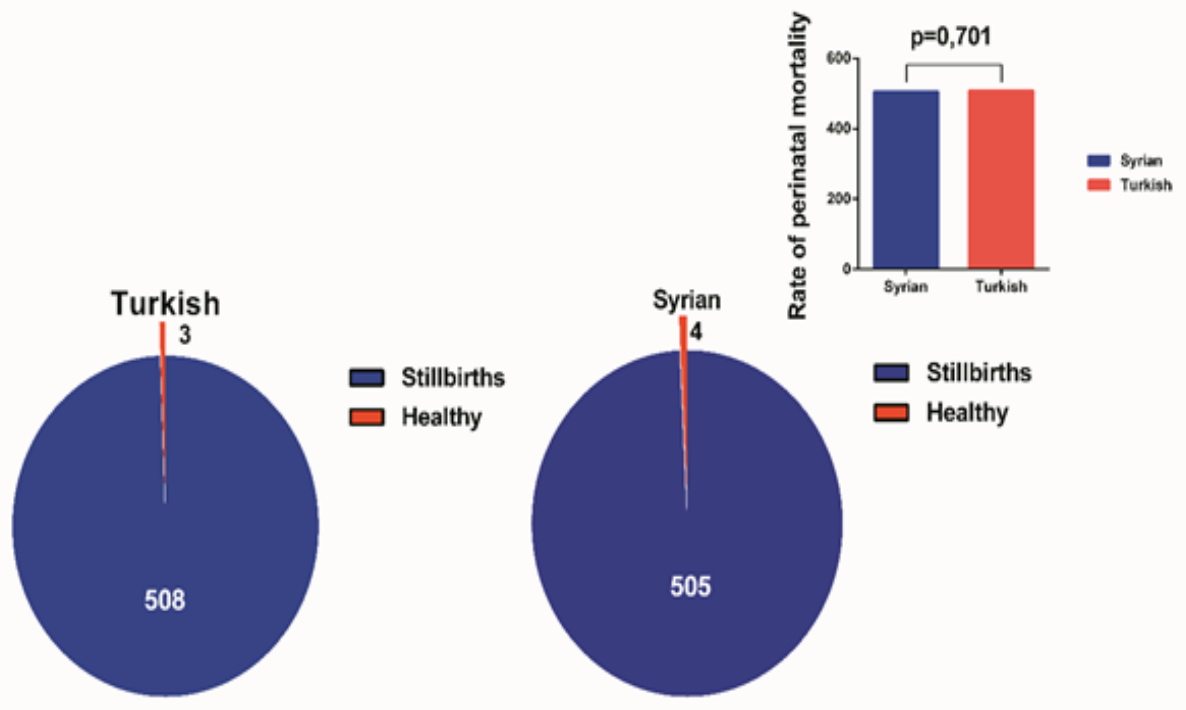

Figure 5. Comparison of the rate of perinatal mortality 
An Evaluation of The Impact of War on Pregnancy in Syrian Refugee Women: A Retrospective Study

Table 1. Comparison of the parameters between Syrian and Turkish women

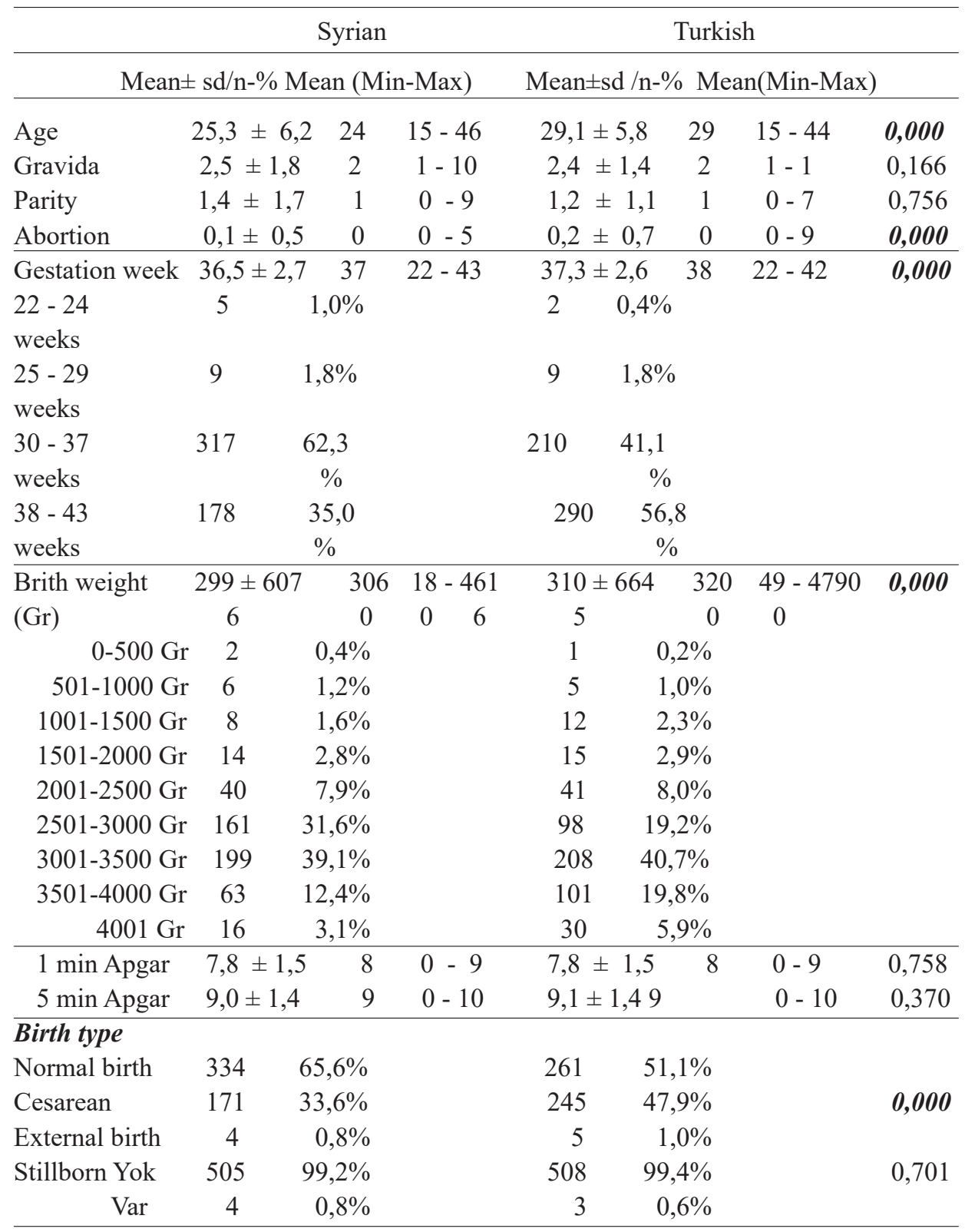

Chi-square test / Mann-Whitney U test 


\section{Discussion}

According to the definition of the World Health Organization (WHO) in 1948; the health is not only the absence of disease and disability, but also a state of complete physical, mental and social well-being (12). The concept of reproductive health was first brought to the agenda at the World Conference on Population and Development held in Cairo in 1994. In addition to the definition of the WHO at the conference, the expression "reproductive health means that individuals have a satisfying and safe sex life, have the ability to reproduce, and have the freedom to decide whether to use this ability" (13). Women's reproductive health can be affected by the environment, socio-cultural and economic factors. Migration, which is a process that affects women in all these aspects, also has negative effects on women's reproductive health (14).

According to the 2014 report of the Prime Ministry Disaster and Emergency Management Presidency, a substantial number of women immigrated to Turkey due to the war that broke out in Syria. In terms of the number of births of Syrian migrant women, it is stated in the report that there were 128 daily births and 70,728 births in total in 2014. However, there is no detailed information about how, where and the results of these births (AFAD, 2014). In addition, the studies around the world have focused on Syrian immigrants in Turkey, which has been dense in number in recent years. According to the Syrian Crisis Regional reports of the United Nations Population Fund (UNFPA), 500,000 of the 1,645,000 Syrian immigrants in Turkey are Syrian women who are in reproductive age. In addition, the report states that 30,000 of these women are pregnant (15). This situation reveals that female immigrants have different and special protection needs compared to male immigrants (16). Otherwise, migrant women may encounter reproductive health problems due to both their gender and genderbased problems (17).

Possible reproductive health problems that migrant women may encounter are summarized as follows. Sexual violence is one of the leading reproductive health problems of Syrian migrant women. It is a situation that women frequently encounter during the migration process. Sexual violence based on gender inequality that immigrant women are exposed to, especially in crisis situations such as war, is one of the most important problems that threaten women's life and security $(17,18)$. Studies show that Syrian migrant women are subjected to sexual violence by their spouses or non-husbands. In addition, it has been determined that sexual violence against women is significantly related to reproductive health. According to a study, the rate of exposure to physical and/or sexual violence among women in war zones is over $30 \%$. It is also estimated that around 6,000 women have been raped since the beginning of the war in Syria. 
In the same study, it is reported that women suffer from more than one type of violence (19).

Most of the migrant women who have been sexually abused do not know their legal rights or do not apply to institutions that can provide support for fear of being deported. Although immigrant women have high reproductive health needs, their access to relevant services and information is limited due to legal, cultural and language barriers $(14,16)$. In the report of the Middle East Strategic Studies Center (ORSAM) titled Impact of Syrian Refugees on Turkey in January 2015, polygamy with Syrian women has become widespread in Turkey. In addition, it is stated that Syrian families make financial gains by marrying their daughters in exchange for money (15). In addition, to a study conducted in Turkey, $6 \%$ of marriages with Syrian migrant women took place in the form of sand marriages (Women's Center Foundation, 2017). This situation results in the abuse of Syrian women. Counseling services should be provided for women who have been sexually abused, primarily on the safety of Syrian migrant women. Especially women who have experienced sexual violence should be directed to the right centers and these women should be provided with free access to necessary services such as treatment and safe shelter. In addition, it is an important need to provide mental health support and rehabilitation services to these women (20). In addition, it is of great importance to regulate criminal sanctions against people responsible for abuse (18).

Immigrant women are more prone to sexual abuse, violence, and sexually transmitted diseases, including Human Immunodeficiency Virus (HIV). Women's reproductive health is overlooked, especially in immigrant camps. According to the results of a study conducted to evaluate the reproductive health and violence status of immigrant women, it was determined that $53.3 \%$ of women had genital tract infections. Similarly, studies conducted in Turkey show that polygamy with immigrant women has become widespread and this is an important reason for the increase in the incidence of sexually transmitted infections. In the study conducted by Gümüş et al. to determine the reproductive health problems of Syrian migrant women, it was determined that $60 \%$ of women had pathological discharge complaints (21). In addition, the immunization levels of Syrian immigrants against Hepatitis B were lower than those of the local people, and it was stated that immigrants should be considered as a risky group in terms of infectious diseases (22).

It is important to carry out regular health screenings of immigrant women in terms of sexually transmitted diseases and to add monitoring and evaluation programs to this service provision. 
In addition, health education for immigrant women on safe sexual life is considered an effective step in preventing sexually transmitted diseases.

Although pregnancy and childbirth are a physiological process, they create a significant burden and stress for the female body. The existence of the infant in mother's womb, physiological changes specific to pregnancy, differences in family and social life are the sources of psychosocial reactions in this process. However, the process of pregnancy and childbirth is generally a joyful and exciting time for the parents. However, the findings of depression, anxiety, stress and distress in pregnant women are increasingly observed today (23). If the gestation period is not planned, especially in susceptible individuals it may emerge as a period of life that cause stress. Stress and anxiety during pregnancy can have negative impacts on pregnancy outcomes and on born children. Maternal stress increases corticotropin releasing hormone (CRH) release from the hypothalamus. Hypothalamus-secreted CRH stimulates pituitary adrenocorticotropin (ACTH) release and ACTH increases glucocorticoid release from the adrenal gland. Glucocorticoids have many effects in every cell of the body.

Glucocorticoids are effective on the production and release of cells involved in the immune system, many cytokines and growth factors. Therefore hypercortisolemia caused by stress can affect pregnancy by affecting many factors (cytokines, immunomodulators, etc.) effecting placenta and fetus (24). As a result, pregnancy is as far away from stress, good nutrition and control is effective on the results such as abortus and preterm delivery.

Psychological and social stress has been indicated to be an independent risk factor for preterm delivery (25). Undoubtedly, war stress and immigration are among the most crucial factors that trigger preterm delivery in women. The findings obtained in our study confirm the triggering effect of stress on preterm delivery. Accordingly, the gestational week in Syrian women was significantly determined lower than those of Turkish women ( $\mathrm{p}<0,05$; Figure 1 ). However, preterm delivery is a multifactorial event, and it is impossible to attribute it to a single factor. Even today, the mechanisms of action of birth are not known precisely. However, $\mathrm{CRH}$ has been revealed to have a birth-onset effect. Therefore, increased CRH due to stress may increase the risk of preterm delivery. Preterm delivery is the leading cause of perinatal mortality and morbidity. However, the perinatal mortality rate recorded in Syrian women who gave birth significantly earlier in our study did not indicate any significant difference compared to the rate recorded in Turkish women ( $>>0,05$; Figure 5) 
Hedegaard et al. (25) have indicated that maternal stress leads to the birth of lowbirth-weight infants and increases the risk of preeclampsia. Our study supports the literature: the birth weight recorded in Syrian women who have undergone intense stress during gestation period was determined to be significantly lower than those of Turkish women $(\mathrm{p}<0,005$; Figure 3$)$. Another reason for the significant low birth weight observed in the Syrian women is considered to be malnutrition and antenatal care because they may be deprived of basic human needs during the immigration and in the camps. As a matter of fact, inadequate nutrition observed in Syrian women has been reported in the literature: Demirci and his colleagues evaluated the births of Syrian immigrants and determined that the new born infants had low birth weight and low hematocrit values (26). In addition, it has been reported that children born under maternal stress are more likely to have Type II diabetes, obesity, hypertension and atopic body in the long term (23).

Animal experiments points out that maternal stress can lead to behavioral disorders in animals in the long term. In humans, there are also studies indicating that children born from mothers who are under stress may be more likely to have behavioral disorders such as irritability, concentration disorder in the long term compared to the general population (27).

In studies conducted in the literature, it has been reported that the antenatal care and the pregnancy age of Syrian immigrant women are lower and the rate of adolescent pregnancy is higher $(28,29)$. In the current study, when the ages of Syrian women, gravida, parity, and abortion ratios were compared with those of Turkish women, the age averages were determined to be significantly lower $(p<0,005$; Figure 1$)$. However, the abortus rates of Syrian immigrant women were interestingly determined lower than those of Turkish women $(p<0,005$; Figure 1). To explain the reason of this decrease, advanced molecular and biochemical studies comparing Syrian women and Turkish women are needed.

When the delivery method of the patients was examined, it was determined that in Syrian patients the normal birth rate was $65,6 \%$, cesarean rate was $33.6 \%$ and external birth was $0.8 \%$ while it was determined that the normal birth rate was $51.1 \%$, the cesarean rate was $47.9 \%$ and the external birth rate was $1.0 \%$ in Turkish patients. In comparison between the groups, the cesarean rate recorded in Turkish patients was determined significantly higher than the cesarean rate recorded in Syrian women ( $\mathrm{p}<0,005$; Figure 2). 
Çift et al. (30), have examined Syrian women and Turkish women in a retrospective study and have observed the newborn infants' Apgar scores, birth weight and birth week. Accordingly, they did not observe a significant difference between the newborn infants' APGAR scores in the study groups. This finding of the literature is consistent with our findings. In the current study, no significant difference between the infants' APGAR scores of Syrian women and Turkish women was observed ( $>0,005$; Figure 4 ). The limitations for the present study can be listed as follows: low number of participants and lack of some information about the participants, such as perinatal information, economic conditions, place where they live and daily life conditions during pregnancy.

\section{Conclusion}

To improve the antenatal care of Syrian immigrant women; we are on the opinion that it is necessary to create ideal solutions by working with international organizations about communication and language. Also, it will contribute to the protection of both health care workers and Syrian immigrants through the inclusion of immigrants in national vaccination programs before pregnancy.

\section{Acknowledgments}

This research received no specific grant from any funding agency in the public, commercial, or not-for-profit sectors.

\section{Conflict of Interest}

Author(s) declare no conflict of interest.

\section{References}

1.Erdoğan M. Türkiye'deki Suriyeliler: Toplumsal Kabul ve Uyum. Ankara: HUGO yayınlar1; 2014.

2.Jessen A. The Government of Turkey and Syrian Refugees 2013. Available at: http://issuu.com/georgetownsfs/docs/jessen_2013_. Accessed 15.05.2021.

3. Şirin EM. Van Merkez İlçe'de Doğurganlık Analizi. Yüksek Lisan Tezi. Van Yüzüncüy1l Üniversitesi; 2012.

4.Aydın R, Körükçü Ö, Kabukçuoğlu K. Bir göçmen olarak anneliğe geçiş: Riskler ve engeller. Psikiyatride Güncel Yaklaşımlar. 2017;9(3):250-62.

5. Grove NJ, Zwi AB. Our health and theirs: forced migration, othering, and public health. Social science \& medicine. 2006;62(8):1931-42.

6. Şimşek Z, Doğan F, Hilali N, Özek B. Bir il merkezinde yaşayan 15-49 yaş evli Suriyeli kadınlarda üreme sağlığı göstergeleri ve hizmet ihtiyacı. 18. Ulusal Halk Sağlığı Kongresi Bildiri Kitabı. 2015. 
7. Başel H, editor İç Göçün Sonuçlari ve İşgücüne Etkileri. Journal of Social Policy Conferences; 2006.

8. Bahadır H, Uçku R. Tanımlayıcı Bir Alan Araştırması: Suriye’li Sığınmacı Kadınların Üreme Sağlığı, İzmir. 18. Ulusal Halk Sağlığı Kongresi. 2015.

9. Büyüktiryaki M, Canpolat FE, Dizdar EA, Okur N, Şimşek GK. Neonatal outcomes of Syrian refugees delivered in a tertiary hospital in Ankara, Turkey. Conflict and health. 2015;9(1):1-2.

10. Erenel H, Mathyk BA, Sal V, Ayhan I, Karatas S, Bebek AK. Clinical characteristics and pregnancy outcomes of Syrian refugees: a case-control study in a tertiary care hospital in Istanbul, Turkey. Archives of gynecology and obstetrics. 2017;295(1):45-50.

11. Tolunay HE, Özcan SC, Şükür YE, Özcan DÖ, Adıbelli FM, Hilali NG. Changes of intraocular pressure in different trimesters of pregnancy among Syrian refugees in Turkey: A cross-sectional study. Turkish journal of obstetrics and gynecology. 2016;13(2):67.

12. Somunoğlu S. Kavramsal açıdan sağlık. Hacettepe Sağlık İdaresi Dergisi. 1999;4(1).

13. Glasier A, Gülmezoglu AM, Schmid GP, Moreno CG, Van Look PF. Sexual and reproductive health: a matter of life and death. The Lancet. 2006;368(9547):1595607.

14. Aksu H, Sevil Ü. Göç ve kadın sağlığı. Maltepe Üniversitesi Hemşirelik Bilim ve Sanatı Dergisi. 2010;2(3):133-8.

15. Aslihan A, Yılmaz DV. Suriyeli göçmen kadınların üreme sağlığı sorunları ve çözüm önerileri. Ege Üniversitesi Hemşirelik Fakültesi Dergisi. 2020;36(2):11725.

16. Arabaci Z, Hasgül E, Serpen AS. Türkiye'de Kadin Göçmenlik ve Göçün Kadin Sağliği Üzerine Etkisi. Sosyal Politika Çalışmaları Dergisi. 2016(36):12944.

17. Adanu RM, Johnson TR. Migration and women's health. International Journal of Gynecology \& Obstetrics. 2009;106(2):179-81.

18. Süt HK. Suriye'den göç eden kadınlar ve üreme sağlığı sorunları. Sağlık ve Toplum. 2017;27(1):3-7.

19. Lancet T. Violence against women in Syria. Elsevier; 2013.

20. Barın H. Türkiye'deki Suriyeli kadınların toplumsal bağlamda yaşadıkları sorunlar ve çözüm önerileri. Göç Araştırmaları Dergisi. 2015(2):10-56.

21. Gümüş Şekerci Y, Bilgili N. Göçün sağlik Üzerindeki Etkileri. 2015. 
22. Keklik Z, Koruk İ. Suriyeli sığınmacılarda hepatit b ve c seroprevalansı ile bu hastalıklarla ilgili bilgi, tutum ve riskli davranış düzeyleri. 19. Ulusal Halk Sağllğ Kongresi. 2017.

23. Halbreich $\mathrm{U}$. The association between pregnancy processes, preterm delivery, low birth weight, and postpartum depressions. The need for interdisciplinary integration. AJOG. 2005;193:1312-22.

24. Knackstedt MK, Hamelmann E, Arck PC. Mothers in Stress: Consequences for the Offsp ring. Am J Reprod Immunol 2005;54:63-9.

25. Hedegaard M, Henriksen TB, Secher NJ, Hatch MC, Sabroe S. Do stress ful life events a.ect duration of gestation and risk of preterm delivery? Epidemiology. 1996;7:339-45.

26. Demirci H, Yildirim TN, Ocakoglu G, Karakulak GM, Ustunyurt E, Ulku TA. Birth characteristics of Syrian refugees and Turkish citizens in Turkey in 2015. J Gynaecol Obstet 2017;137(1):63-6.

27. Glover V, Connor O. Effects of ante natal stress and anxiety: implications for development and psychiatry. Br J Psychiatry. 2002;180:389-91.

28. Alnuaimi K, Kassab M, Ali R, Mohammad K, Shattnawi K. Pregnancy outcomes among Syrian refugee and Jordanian women: a comparative study. Int Nurs Rev 2017.

29. Erenel H, Aydogan MB, Sal V, Ayhan I, Karatas S, Koc BA. Clinical characteristics and pregnancy outcomes of Syrian refugees: a case-control study in a tertiary care hospital in Istanbul, Turkey. Arch Gynecol Obstet 2017;295(1):4550.

30. Çift T, Temur M, Korkmazer E, Saygı İA, Ballı Ö, Üstünyurt E. Türkiye ve Suriyeli Göçmen Kadınlara ait Gebelik ve Seroloji Sonuçlarının Karşılaştırılması. Smyrna Tip Dergisi. 2017:5-11 